\title{
SEJARAH DESA LAIBA KECAMATAN PARIGI KABUPATEN MUNA TAHUN 1978-2017
}

\author{
Oleh \\ Karfila $^{2}$, Rifai Nur
}

\begin{abstract}
ABSTRAK: Masalah utama dalam penelitian ini adalah: (1) Apa latar belakang terbentuknya Desa Laiba Kecamatan Parigi Kabupaten Muna? (2) Bagaimana perkembangan Desa Laiba Kecamatan Parigi Kabupaten Muna Tahun 1978-2017? Penelitian ini menggunakan metode sejarah dengan mengacu pada Kuntowijoyo, yang terdiri atas lima tahap, sebagai berikut: (1) Pemilihan topik, (2) Heuristik yang terdiri dari Penelitian kepustakaan, Pengamatan, Wawancara, dan Studi dokumen. (3) Verifikasi, yang terdiri dari kritik ekstern (kritik luar) dan kritik intern (kritik dalam). (4) Interpretasi, yang terdiri dari analisis (menguraikan) dan sintesis. (5) Penulisan Sejarah. Kajian pustaka dalam penulisan ini terdiri atas (1) Konsep Pemerintah, (2) Konsep Otonomi, (3) Konsep Pemekaran, (4) Konsep Perkembangan, (5) Konsep Sistem dan Struktur, (6) Penelitian Relevan.

Hasil peneltian menunjukkan bahwa: (1) Latar belakang terbentuknya Desa Laiba Kecamatan Parigi Kabupaten Muna, yaitu terbentuknya Desa Laiba tidak terlepas dari peran para pemimpin dan tokoh adat sebagai motivator dan dinamisator. Selain itu juga terbentuknya Desa Laiba karena faktor geografis dan faktor demografi (2) Perkembangan Desa Laiba Kecamatan Parigi Kabupaten Muna tahun 1978-2017 secara umum, bahwa perkembangan politik yang ada di Desa Laiba sudah cukup baik meskipun pada tahun 2014 kondisi politiknya gaduh akan tetapi setelah berjalannya waktu keadaan itu sudah kembali stabil. Kemudian dari segi ekonomi menunjukkan perkembangan yang lebih baik dan maju menuju arah yang semakin sejahtera dengan memanfaatkan potensi-potensi sumber daya alam yang ada di Desa tersebut. Selanjutnya karena kondisi ekonomi sudah cukup baik maka keadaan pendidikanpun ikut membaik, sarana dan prasaranapun yang ada di desa ini semakin memadai. Sedangkan keadaan sosial budaya Desa Laiba menunjukkan keadaan yang lebih baik.
\end{abstract}

\section{Kata Kunci: Latar Belakang, Perkembangan, Desa Laiba}

\section{PENDAHULUAN}

Pelaksanaan pembangunan nasional merupakan pembangunan yang dilaksanakan bangsa Indonesia yang dilakukan oleh pemerintah dan seluruh rakyat dalam rangka pembangunan itu harus dimulai dari unit pemerintah yang terendah di dalam struktur pemerintahan. Desa merupakan kesatuan masyarakat hukum yang memiliki batas-batas wilayah yang berwenang untuk mengatur dan mengurus kepentingan masyarakat setempat berdasrkan asal-usul dan adat istiadat yang diakui dan dihormati dalam pemerintahan Negara Kesatuan Republik Indonesia (NKRI).

Menurut Widjaja (2002: 21) proses peralihan dari sistem dekonsentrasi kesistem desentralisasi disebut pemerintahan daerah dengan otonomi. Otonomi adalah penyerahan urusan pemerintah kepada Pemerintah Daerah yang bersifat operasional dalam rangka sistem birokrasi pemerintahan. Tujuan otonomi adalah untuk mencapai efektivitas dan efesiensi dalam pelayanan kepada masyarakat. Selanjutnya yang dikemukakan oleh Pamuji (1985: 10) mengatakan bahwa, "dalam rangka mencapai tujuan sistem (juga sistem pemerintahan) itu berproses, dalam proses mana diperlukan masukan (input) dan setelah melalui proses konversi akan menghasilkan keluaran (output). Keluaran (output) ini selanjutnya akan merupakan umpan balik (feedback) dan menjadi masukan (input) bagi suatu konvensi baru, dengan keluaran baru lebih baik. Demikian seterusnya sehingga dalam segi lain suatu sistem tadi merupakan suatu proses dinamik yang berjalan terus

\footnotetext{
${ }^{1}$ Disandur dari hasil Penelitian

${ }^{2}$ Alumni Jurusan Pendidikan Sejarah

${ }^{3}$ Dosen FKIP UHO
} 
dimana masukan dikonversi menjadi keluaran yang selanjutnya keluaran akan menjadi umpan balik bagi konversi baru sebagai masukan baru dan menghasilkan keluaran baru".

Menurut Subarno (2007: 76) menyatakan bahwa rumusan tujuan kebijakan pemekaran daerah telah banyak dituangkan dalam berbagai kebijakan-kebijakan yang ada selama ini, baik dalam Undang-Undang maupun Peraturan Pemerintah. Diantara faktor yang mendorong terjadinya pemekaran desa adalah fenomena pertumbuhan penduduk di daerah pedesaan yang terus meningkat dengan senantiasa memperhatikan potensi-potensi desa, sarana dan prasarana, serta kehidupan sosial-ekonomi masyarakat pedesaan. Padatnya penduduk dibeberapa wilayah pedesaan dapat mempengaruhi sistem pelayanan publik yang tidak optimal oleh wilayah induk. Kondisi ini memicu terjadinya berbagai ketimpangan dalam pengalokasian aset dan sumber daya kepada seluruh dusun, misalnya pembangunan infrastruktur, pemberdayaan masyarakat, peningkatan pelayanan kepada masyarakat dan hal-hal lain yang tidak berjalan merata. Oleh karena itu, pemekaran desa baru menjadi salah satu alternative untuk mengatasi permasalahan dimaksud sekaligus juga untuk meningkatkan pelayanan kepada masyarakat.

Menurut Emile Durkheim (1855-1917) menyatakan bahwa unsur baku dalam masyarakat adalah faktor solidaritas yang membedakan antara masyarakat yang bercirikan faktor solidaritas mekanis dengan yang memiliki solidaritas organis. Pada masyarakat-masyarakat solidaritas mekanis, warga-warga masyarakat mempunyai diferensiansi dan pembagian kerja. Lagi pula para warga masyarakat mempunyai kepentingan-kepentingan yang sama dan kesadaran yang sama pula. Masyarakat dengan solidaritas organis yang merupakan perkembangan dari masyarakat dengan solidaritas mekanis, telah mempunyai pembagian kerja yang ditandai dengan derajat spesialisasi tertentu. Apabila solidaritas tersebut mengalami kemunduran, maka mungkin timbul keadaan anomie, dimana para warga masyarakat tidak lagi mempunyai pedoman untuk mengukur kegiatan-kegiatan dengan nilai dan norma yang ada (Soekanto, 2015:34).

Disamping itu juga didukung oleh faktor demografinya yang dimana turut pula mendukung terbentuknya desa. Potensi penduduk ini sangat penting dalam mengelola secara komprehensif potensi yang ada. Dalam pelaksanaan pemerintah dibutuhkan orang-orang yang kompoten dalam pemerintahan, bisa dibayangkan jika disuatu daerah tidak memiliki penduduk, kemungkinan tidak ada aktivitas kegiatan didaerah ini. Sumber daya manusia (SDM) yang berkualitas dan handal sangat diperlukan terutama bagi generasi muda. Demikian juga terbentuknya Desa Laiba (Liwu Laiba) karena didukung oleh faktor keadaan ekonomi yang merupakan dasar dalam pembangunan wilayah, baik itu potensi ekonomi maupun potensi pertanian dan perkebunan (agro ekonomi ).

\section{METODE PENELITIAN}

Sesuai dengan judul penelitian ini maka yang menjadi tempat atau lokasi penelitian adalah di Desa Laiba Kecamatan Parigi Kabupaten Muna. jenis penelitian sejarah deskriptif kualitatif dan pendekatan strukturis. Penelitian deskriptif kualitatif adalah suatu jenis penelitian dimana peneliti berusaha mendeskripsikan data-data dan fakta-fakta yang diperoleh berdasarkan bahan informan/temuan dari obyek yang diteliti di lapangan atau lokasi penelitian. Pendekatan strukturis adalah pendekatan yang mempelajari peristiwa dan struktur sebagai satu kesatuan yang saling melengkapi. Artinya peristiwa mengandung kekuatan mengubah struktur sosial, sedangkan struktur mengandung hambatan atau dorongan bagi tindakan perubahan dalam masyarakat.

Sumber tersebut dapat dijelaskan sebagai berikut: Sumber tertulis, Sumber lisan, Sumber visual. Metode yang digunakan dalam penelitian ini adalah motode sejarah yang mengacu pada pendapat Kuntowijoyo (1995: 89) yang membagi metode sejarah dalam lima tahapan yaitu: Pemilihan Topik, Heuristik, Verifikasi (kritik ekstern dan kritik intern), Interpretasi terdiri atas analisis dan sintesis, penulisan sejarah

\section{HASIL PENELITIAN DAN PEMBAHASAN}




\section{Latar Belakang Terbentuknya Desa Laiba Kecamatan Parigi Kabupaten Muna}

Desa Laiba adalah bukanlah desa yang baru terbentuk, bahkan Desa Laiba merupakan salah satu desa tertua yang ada di wilayah Parigi. Awalnya Desa Laiba merupakan bagian dari Kampung Foopanda (sekarang Desa Wantiworo) Kecamatan Kabawo, nanti pada tahun 1978 Desa Laiba baru dimekarkan dari Kampung Foopanda menjadi Kampung Laiba yang dikepalai oleh La Ode Ntumade, sebelum menjadi sebuah wilayah defenitif wilayah Desa Laiba sangat luas sehingga para toko adat bermusyawarah untuk membagi Kampung Laiba menjadi tiga kampung, yakni Kampung Laiba sendiri, Kampung Latampu dan Kampung Labulubulu. Setelah satu tahun kemudian kampung ini baru menjadi sebuah wilayah yang defenitif yaitu "Desa Laiba" Kecamatan Parigi Kabupaten Muna yang ibukota kecamatannya adalah parigi yang berada di Desa Wasolangka. Berdasarkan hasil wawancara beberapa informan mengatakan bahwa asal-usul pemberian nama Desa Laiba adalah diambil dari nama salah seorang penduduk Desa Laiba yang pada saat itu bertemu dengan La Kakoda (Putra Sugi Manuru) Raja Muna. Sugi Manuru memiliki delapan (8) orang anak yang kesemuanya diutus untuk mengepalai tiap-tiap kampung yang ada di Muna.

Menurut cerita pada suatu hari La Kakoda melakukan perjalanan hingga ia sampai di Kampung Laiba. Sesampainya di Kampung Laiba ia bertemu dengan salah seorang petani, kemudian terjadilah percakapan diantara mereka. La Kakoda menanyakan nama kampung tersebut namun kampung itu belum ada namanya jawab petani itu, kemudian La Kakoda bertanya kembali siapakah nama anda? Petani itu menjawab nama saya adalah "La Iba". Lanjut La Kakoda, "kalau begitu kampung ini saya beri nama Kampung Laiba. Kemudian La Kakoda memperkenalkan dirinya dan menjelaskan maksud atau tujuannya datang ke kampung tersebut. Saya adalah La Kakoda putra dari Sugi Manuru maksud kedatangan saya disini adalah saya diutus oleh ayah saya untuk mengepalai Kampung ini. Mendengar penjelasan itu petani tadi langsung sujud dan meminta maaf. Hari demi hari cerita kedatangan La Kakoda dan pemberian nama Kampung Laiba semakin tersebar dan akhirnya sejak saat itu nama Kampung itu di sebut Kampung Laiba sekarang Desa Laiba. Pada tahun 1978 Desa Laiba dimekarkan dan yang menjadi kepala Desa pelaksana adalah La Ode Ntumade. Setelah satu tahun kemudian Desa Laiba baru menjadi sebuah Desa yang defenitif dan masih dikepalai oleh La Ode Ntumade. Pada saat pemerintahan La Ode Ntumade wilayah Desa Laiba dibagi menjadi dua (2) dusun, yakni Dusun I yang diketuai oleh Bapak La Pera dan Dusun II yang di ketuai oleh Bapak La Ode Jiino.

Pemerintahan La Ode Ntumade oleh masyarakat menganggapnya sangat ketat juga bijak karena apabila ia mendapati anak remaja pada saat jam kerja berkeliaran atau jalan-jalan tanpa tujuan yang jelas maka ia tidak segan-segan untuk memarahinya bahkan ia melakukan kekerasan fisik. Tujuan dari sikapnya tersebut tidak lain adalah untuk menyadarkan masyarakat bahwa pentingnya menghargai waktu dan demi kesejahteraan hidup masyarakatnya. La Ode Ntumade memerintah selama 6 tahun dan sejak pemerintahannya masyarakat sangat antusias dalam melakukan berbagai pembangunan. La Ode Ntumade memerintahkan kepada masyarakatnya untuk membangun dan membuka lahan perkebunan tetap, penanaman kelapa, penanaman jambu mette, membuka jalan yang menuju perkebunan, membuka tanah desa, penataan lingkungan desa, pembangunan kantor desa, pembangunan SD dan pembangunan lainnya (Wawancara beberapa orang informan, 11 Oktober 2018).

Setelah selesai masa jabatannya maka masyarakat Desa Laiba melakukan pemilihan kepala desa dan yang terpilih adalah Bapak La Dika. Pada masa pemerintahannya membagi wilayah Desa Laiba menjadi 4 dusun, yakni Dusun I yang diketuai oleh Bapak La Ode Mposuru, Dusun II yang dikepalai oleh Bapak La Ode Suano, Dusun III yang diketuai oleh Bapak La Bau, dan Dusun IV di ketuai oleh Bapak La Ode Jiino. Pembagian wilayah Desa Laiba menjadi 4 dusun guna untuk mempermudah dalam melakukan pembaharuan. Semasa jabatannya Bapak La Dika mendirikan sebuah Masjid dan pembangunan sebuah gedung sanggar PKK yang diperoleh bantuan dari pemerintah, yakni DPD dan Swadaya. Bapak La Dika menjabat selama 6 tahun dan tidak terlalu banyak melakukan pembaharuang karena hanya melanjutkan pembangunan yang dilaksanakan oleh kepala desa sebelumnya. Setelah selesai masa jabatannya maka masyarakat melakukan pemilihan 
kembali dan yang terpilih adalah Bapak La Tia. Pada masa pemerintahan Bapak La Tia pembangunan yang dilakukan cukup baik yakni ia melakukan pembangunan jalan usaha tani dusun I dan pembangunan perkerasan jalanan dusun II yang diperoleh dana dari PKK.

Masa jabatan Bapak La Tia selama 5 tahun karena mengundurkan diri dan yang menjadi Kepala Desa pelaksana adalah Bapak Drs. Edi Ridwan. Setelah selesai masa jabatan masyarakat melakukan pemilihan kepala desa lagi dan yang terpilih adalah Bapak La Ode Ndomuka, masa jabatan La Ode Ndomuka selama 7 tahun. Pembangunan yang dilakukannya adalah pembuatan jalan Desa Laiba menuju Desa Latampu dan perenovasian gedung-gedung yang sudah lapuk yang diperoleh dana dari PPIP. La Ode Ndomuka oleh masyarakat diberi gelar Yaro pata nihanda. Setelah selesai masa jabatannya pada tahun 2007 masyarakat melakukan pemilihan kembali dan yang terpilih adalah Bapak Rahmat Sufa, S. Pd.

Pada masa pemerintahan Bapak Rahmat Sufa, ia membagi wilayah Desa Laiba menjadi 2 dusun, yakni dusun I yang di ketuai oleh Bapak La Ode Suano dan Dusun II diketuai oleh Bapak La Ode Talifu. Pembangunan yang dilakukannya adalah pembuatan lapangan sepak bola yang didanai oleh APBD I, pembangunan sumur gali yang didanai oleh PNPM, dan pembangunan gedung TK yang didanai oleh PNPM. Masa jabatan Rahmat Sufa selama 7 tahun. Setelah selesai masa jabatan, maka penduduk Desa Laiba kembali melakukan pemilihan dan yang terpilih adalah Bapak La Jia dengan selisih 1 suara karena lawan politiknya tidak menerima hasil dari pemilihan tersebut maka dilakukan berbagai cara untuk ditiadakannya pelantikan bahkan kantor balai desa dihancurkan. Setelah 3 bulan kemudian baru La jia dilantik dan menjabat sampai sekarang tahun 2017. Pada masa pemerintahan La Jia mula-mula yang ia lakukan adalah sesuai visi dan misinya yaitu "Mewujudkan Kesejahteraan Masyarakat Desa Laiba Dengan Mengembangkan Sumber Daya Alam Pertanian, Perdagangan, Perkebunan Dan Pariwisata Yang Berlandaskan Iman Dan Taqwa". Pada masa pemerintahan La Jia pembangunan yang dijalankan sudah semakin maju dibandingkan dengan sebelumnya, pada tahun 2015 dibangun mesjid dari dana Dana Desa (DD), perkerasan jalan menuju Labulu-bulu, dan pembangunan kantor Desa. Jika dilihat dari pertama terbentuknya Desa Laiba dari tahun 1978 hingga 2017, bisa ditarik kesimpulan bahwa pembangunan Desa Laiba sudah cukup baik. Pembangunan Desa Laiba mengalami keterpurukan pada tahun 2014 yakni, pada saat pergantian kepemimpinan tampak bahwa kondisi politiknya yang gaduh. Tetapi setelah pelantikan kepala desa terpilih kondisi politik itu sudah membaik.

\section{Asal-Usul Penduduk Desa Laiba}

Berbicara soal masyarakat Indonesia, kita tentu tahu betul betapa beragamnya suku-suku yang ada. Di Indonesia sendiri istilah" "pribumi" biasanya digunakan untuk mengacu pada identitas asal daerah seseorang. Mengenal suku dan asal-usul diri tentu bukan hal yang salah, justru merupakan hal yang baik bisa mengenal identitas diri sendiri. Namun sayangnya, terkadang identitas ini justru digunakan untuk membedakan mereka yang penduduk asli dan pendatang pada daerah tertentu.

Berdasarkan informasi yang diperoleh oleh penulis mengenai asal-usul penduduk Desa Laiba merupakan penduduk yang sudah mendiami wilayah tersebut sebelum dibentuknya Desa Laiba, dalam hal ini penduduk Desa Laiba merupakan penduduk asli yang mendiami wilayah tersebut, yang pada dasarnya bertempat tinggal di desa ini merupakan suku Muna, yang umumnya hidup dalam suatu wilayah bersama. Seiring perkembangan zaman saat ini penduduk Desa Laiba makin bertambah dan suku-suku lain juga berdatangan di desa ini seperti suku Bugis, Tolaki, Bajo dan lain sebagainya (wawancara beberapa orang informan, Oktober 2018). Berdasarkan keputusan pemerintah dan para toko adat kampung Laiba maka pada tahun 1978 terbentuklah Desa Laiba Kecamatan Parigi Kabupaten Muna. Terbentuknya Desa Laiba karena pemerintah melihat kondisi pertumbuhan penduduk semakin meningkat.

\section{Pembentukan Desa Laiba}

Desa dibentuk atas prakarsa masyarakat dengan memerhatikan asal-usul Desa, jumlah penduduk, luas wilayah dan kondisi sosial budaya masyarakat setempat. Pembentukan Desa dapat berupa penggabungan beberapa desa atau bagian desa yang bersandingan, atau pemekaran dari satu desa menjadi dua desa atau lebih, pembentukan desa di luar desa yang telah ada. Awal 
terbentuknya Desa Laiba tidak terlepas dari kesepakatan pemerintah Desa Laiba untuk melakukan pemekaran dari Kampung Foopanda menjadi kampung Laiba. Kampung Laiba terbentuk pada tahun 1978 dan menjadi wilayah defenitif pada tahun 1979, yakni "Desa Laiba" yang merupakan hasil kesepakatan pemerintah dan peran para toko adat Desa Laiba. Masyarakat beranggapan bahwa dengan mekarnya Desa Laiba dapat mempermudah pembangunan yang ada di Desa Laiba (Wawancara, La Ode Ndipolo, 10 Oktober 2018). Adapun uraian latar belakang pembentukan Desa Laiba adalah sebagai berikut:

\section{a. Jumlah Penduduk}

Penduduk yaitu orang-orang yang berada dalam suatu wilayah tertentu. Penduduk merupakan salah satu syarat berdirinya suatu wilayah atau desa harus memiliki sumber daya manusia (SDM) yang berkualitas dan handal sangat diperlukan dalam suatu pembentukan desa. Pelaksanaan pemerintah dibutuhkan orang-orang yang berkompoten dibidang pemerintahan sebab jika di suatu daerah tidak memiliki penduduk, maka kemungkinan tidak ada aktivitas kegiatan di Desa Laiba. Kriteria atau persyaratan minimal jumlah penduduk harus memenuhi persyaratan, sebagaimana peraturan dalam pembentukan satu desa bahwa jumlah penduduk seharusnya minimal 400 jiwa dan maksimal 1000 jiwa khususnya daerah Sulawesi. Pada saat terbentuknya Desa Laiba Jumlah penduduknya 2800 jiwa, ini menunjukkan bahwa kriteria dan syarat terbentuknya sebuah desa sudah terpenuhi (Profil Desa Laiba 2017).

\section{b. Luas Wilayah}

Luas wilayah yang mejadi cakupan suatu desa menjadi alasan yang cukup kuat dalam pembentukan suatu desa. Wilayah desa yang terlalu luas secara langsung memberikan dampak yang signifikan dalam menentukan program-program pembangunan desa. Besaran anggaran yang dialokasikan untuk desa kurang memberikan kontribusi bagi masyarakat mengingat luasnya jangkauan wilayah desa yang harus dibenahi. Oleh karena itu, aspirasi masyarakat berkembang untuk mengusulkan pembentukan desa dengan harapan wilayah desa yang baru dibentuk akan lebih efisien menyerap dana yang dialokasikan dalam pembangunan desa. Luas wilayah Desa Laiba pada saat terbentuk yakni $16000 \mathrm{Ha}$, demikian pula halnya dengan latar belakang terbentuknya Desa Laiba dengan kondisi wilayah beserta potensi yang ada didalamnya karena pertimbangan yang cukup strategis sehingga memungkinkan berhubungan antar Desa Laiba dan pemerintah kabupaten bahkan dengan pemerintah provinsi yang dimana tadinya hanya sebuah kampung yang kemudian menjadi desa yang defenitif.

\section{c. Sosial Budaya}

Dengan adanya kultur dan budaya masyarakat yang relatif sama dapat menjadi pertimbangan dalam pembentukan suatu desa. Pelestarian nilai-nilai budaya dapat dilaksanakan dan berpengaruh secara langsung dalam pengaturan tatanan kehidupan masyarakat desa. Melalui kegiatan pembangunan dalam bidang sosial budaya diharapkan antara masyarakat yang mendiami Desa Laiba baik yang beragam suku yang ada didalamnya maupun pemerintah terjalin hubungan yang harmonis, hormat-menghormati, guna dalam menciptakan suasana yang harmonis dan kondusif sehingga dapat meningkatkan taraf hidup dan kesejahteraan masyarakat yang ada di Desa Laiba. Kegiatan pembangunan dalam bidang sosial di Desa Laiba sudah terwujud sebelum Desa Laiba dimekarkan, pembangunan yang dimaksud seperti melalui saluran-saluran organisasi sosial. Organisasi sosial tersebut dimaksudkan sebagai wadah untuk menghimpun para warga masyarakat seluruh potensi yang dimiliki oleh daerah setempat sehingga dikenal dengan sistem budaya pokadulu (gotong royong) yang masih tetap terwujud kelestariannya hingga sekarang ini, yang diwujudkan dalam bentuk kerja sama, baik sesama pemerintah maupun sesama anggota masyarakat setempat yang saling mendukung dalam perjuangan pembentukan Desa Laiba. Sistem budaya pokadulu (gotong royong) ini sering dilakukan jika ada kegiata-kegiatan apa saja dalam lingkungan desa maupun sesama masyarakat sendiri sehingga wujud hubungan timbal balik yang harmonis dalam lingkungan Desa Laiba. Selain itu juga budaya yang masih dilestarikan sampai sekarang oleh masyarakat Desa Laiba adalah kaago-ago (ritual), masyarakat percaya bahwa dengan dilaksakannya ritual ini kehidupan masyarakat akan tenang jauh dari segala marabahaya dan ritual ini dilaksanakan satu tahun sekali. 


\section{d. Ekonomi}

Kondisi ekonomi merupakan salah satu syarat untuk mendukung percepatan pembentukan sebuah desa. Keadaan ekonomi masyarakat Desa Laiba merupakan dasar dalam pembangunan wilayah, baik itu potensi ekonomi, pertanian, perkebunan, industri pengolahan, industri rumah tangga maupun pemasukan terhadap konstribusi pajak yang dibayarkan oleh masyarakat guna pembangunan daerah. Usaha bidang pertanian dan perkebunan di wilayah ini merupakan indikator yang mendukung aspek ekonomi dalam pembentukan desa.

\section{e. Peran Pemimpin Dalam Pembentukan Desa}

\section{a) Sebagai motivator}

Sebagai salah satu kenyataan yang terjadi dalam sebuah komunitas terutama di negaranegara berkembang adalah banyaknya kekurangan dan keterbatasan yang dimiliki oleh masyarakat baik dalam tingkat pendidikan yang relatif rendah maupun tingkat ekonomi yang tergolong lemah dengan penghasilan sedikit. Kendala tersebut sangatlah mempengaruhi cara berfikir dan kreatifitas dalam upaya meningkatkan kesejahteraan hidup mereka. Keterbatasan-keterbatasan yang dimaksud merupakan tantangan semangat jiwa para pemimpin. Untuk mengantisipasi hal tersebut maka para pemimpin yang berada di Desa Laiba turut serta memberikan motivasi kepada warganya agar mereka dapat berpatisipasi aktif dalam setiap kegiatan yang sifatnya membangun. Oleh karena itu, kehadiran para pemimpin Desa Laiba sebagai motivator merupakan andil yang cukup besar guna menyukseskan program-program yang ingin dicapai.

Kesepakatan pemimpin di Desa Laiba dalam setiap kegiatan sangat besar pengaruhnya yang bersifat kharismatik, para warga sangat loyal dan memiliki respon yang kuat untuk mengikuti apa yang dikatakan oleh pemimpin tersebut. Jadi sehubungan dengan hal ini kesepakatan pemimpin sangat diperlukan terutama dalam upaya untuk memenuhi motivasi warga masyarakat untuk ikut serta secara langsung dalam setiap program yang direncanakan. Sehubungan dengan terbentuknya Desa Laiba, kesepakatan pemimpin tokoh masyarakat, tokoh agama selaku motivator yang memberikan dorongan atau motivasi kepada seluruh warga masyarakat agar senantiasa berpartisipasi aktif dalam usaha pembentukan Desa Laiba.

Peran selanjutnya yang ditimbulkan pemimpin Desa Laiba kepada warga masyarakat adalah partisipasi informatif yakni partisipasi dalam menerima dan memberi informasi. Hal ini sangat penting untuk menumbuhkan kesadaran dan semangat dalam setiap individu sebagai anggota masyarakat akan perlunya membentuk sebuah komunitas (desa) yang terstruktur dan terorganisasi. Dengan terbentuknya Desa Laiba maka dapat dikatakan bahwa tingkat kesadaran masyarakat telah tumbuh dan berkembang motivasi dan kepemimpinan para pemimpin informal. Selain itu partisipasi yang ditimbulkan adalah partisipasi responsive yakni masyarakat memberikan tanggapan, pendapat dan saran-saran yang sifatnya konstruksi dalam menyusun kegiatan maupun dalam pelaksanaannya (Wawancara Rahmat Sufa, 11 Oktober 2018).

\section{b) Sebagai Dinamisator}

Peran pemerintah sebagai dinamisator adalah menggerakkan partisipasi masyarakat jika terjadi kendala-kendala dalam proses pembangunan untuk mendorong dan memelihara dinamika pembangunan daerah. Bukan hanya sekedar basa-basi atau slogan kosong apabila seorang pemimpin informal di dalam dan diluar lingkungan pemerintah sering mengatakan bahwa penyelenggaraan dan pembangunan desa merupakan perjuangan. Bukan pula tanpa dasar yang kuat apabila pemimpin itu berkata bahwa kondisi masyarakat yang dicita-citakan tidak datang dengan sendirinya tanpa bekerja keras. Memang kenyataan jika ada pendapat yang menyatakan nasib suatu bangsa pada analisa terakhir berada ditangan bangsa yang bersangkutan sendiri, maka salah satu implikasi operasional adalah mutlak perlunya dinamika yang tinggi untuk menyelenggarakan pembangunan desa yang telah disepakati bersama.

Memberikan bimbingan dan pengarahan itulah cara yang paling efetktif dapat dilakukan antara pemimpin informal dengan aparat pemerintah desa dalam rangka menaikan peranan sebagai dinamisator. Dikatakan dapat efektif karena status mereka dalam masyarakat, disamping pengaruh pengetahuan yang dimiliki tentang berbagai segi kehidupan masyarakat yang khususnya yang 
menyangkut penyelenggaraan pembangunan desa (Wawancara, La Ode Talifu, 11 Oktober 2018). Syarat pendukung terbentuknya Desa Laiba yaitu adanya berbagai macam potensi salah satunya dibidang ekonomi, dan pertumbuhan penduduk serta kesepakatan para pemimpin Desa Laiba selaku dinamisator sangat penting dalam rangka proses pembentukan Desa Laiba. Kemudian memberikan bimbingan dan pengarahan kepada masyarakat Laiba mengingat pentingnya membentuk sebuah desa yang dilakukan secara musyawarah dan mufakat.

Berdasarkan Undang-Undang Desa No. 6 Tahun 2014 syarat-syarat terbentunya daerah, sebagaimana yang tertera pada Pasal 8 Ayat 3 Tentang Pembentukan dan Susunan Daerah yang berbunyi "daerah dibentuk berdasarkan perimbangan kemampuan ekonomi, potensi daerah, sosial budaya, sosial politik, jumlah penduduk, luas daerah dan perimbangan yang lain. Dari persyaratan yang telah dipenuhi dalam pembentukan daerah tersebut dapat digolongkan sebagai faktor utama yang harus dipenuhi dalam pembentukan suatu wilayah baik provinsi, kabupaten, kecamatan. Desa Laiba terbentuk berdasrkan jumlah penduduk yang bisa digolongkan sebagai faktor utama terbentuknya desa (profil desa tahun 2017). Adapun syarat utama terbentuknya Desa Laiba adalah sebagai berikut:

\section{a. Keadaan Geografis}

Dukungan wilayah dalam rangka pelaksanaan pemerintah baik setiap negara, provinsi, kabupaten, kecamatan, dan kelurahan/desa merupakan hak yang mutlak. Letak geografis yang dimiliki desa ini sangat strategis karena merupakan suatu desa yang mudah berhubungan dengan wilayah kecamatan bahkan wilayah kabupaten yang bisa dilalui dengan jalur darat. Untuk memenuhi kebutuhan hidupnya sehari-hari masyarakat di daerah ini sebagian besar menggantungkan hidupnya dibidang pertanian, perkebunan, pertukangan, perdagangan maupun dibidang lainnya. Potensi desa adalah gambaran keadaan yang dimiliki oleh wilayah desa berupa sumber daya baik sumber daya alam maupun sumber daya manusia yang meliputi potensi umum dan potensi khusus. Potensi umum adalah segala sesuatu yang ada dalam masyarakat yang penggunaanya tidak terbatas orang perorang tetapi dapat digunakan oleh siapa saja dan kapan saja. Potensi yang dimaksud adalah jalan, jembatan, rumah ibadah, mata air, laut, kantor dan lain sebagainya. Sedangkan potensi khusus adalah segala sesuatu yang ada dalam masyarakat tetapi penggunaanya tidak secara umum tetapi berorientasi pada orang perorang, seperti lokasi pertanian, perumahan, ternak dan lain-lain. Desa Laiba memiliki berbagai potensi dalam penunjang kelangsungan hidup masyarakat, baik itu potensi umum maupun potensi khusus. Wilayah ini merupakan daerah yang terdiri dari daratan dan pegunungan didalamnya mengandung potensi sumber daya alam yang terdiri dari kayu, batu kapur, dan lain-lain. Desa Laiba juga merupakan kawasan yang sangat cocok untuk daerah pertanian, perkebunan, dan peternakan (Wawancara La jia, 9 Oktober 2018).

\section{b. Keadaan Demografi (Penduduk)}

Keadaan penduduk turut pula mendukung terbentuknya desa, potensi penduduk ini sangat penting dalam mengelola secara komprehensif potensi yang ada. Pelaksanaan pemerintah dibutuhkan orang-orang yang berkompoten dibidang pemerintahan sebab jika disuatu daerah tidak memiliki penduduk, maka kemungkinan tidak ada aktivitas kegiatan yang dijalankan, penduduk inilah sebagai pendukung aktivitas kegiatan di Desa Laiba. Dengan memiliki sumber daya manusia yang berkualitas dan handal sangat diperlukan terutama bagi pembentuk sebuah desa. Dilihat dari sumber daya manusia masyarakat Desa Laiba masih berada dibawah rata-rata dimana mayoritas penduduknya hanya berpendidikan SD, SMP, SMA, dan S1. Tetapi dalam hal pekerjaan didalamnya terdapat berbagai profesi baik sebagai petani, pedagang, pertukangan, dan sebagian kecil PNS. Dalam hal pelaksanaan pembangunan di Desa Laiba banyak tenaga kerja yang profesional yang telah berpengalaman berpartisipasi dalam berbagai program.

\section{A. Perkembangan Desa Laiba Kecamatan Parigi Kabupaten Muna tahun 1978-2017}




\section{E-ISSN: 2502-6674}

P-ISSN: 2502-6666

http://ojs.uho.ac.id/index.php/p_sejarah_uho

Perkembangan Desa Laiba dapat dilihat dari beberapa aspek, diantaranya perkembangan politik, perkembangan pelayanan umum, perkembangan dibidang ekonomi, perkembangan dibidang pendidikan dan perkembangan sarana dan prasarana. Untuk lebih jelasnya, maka dapat didefenisikan dalam beberapa penjelasan dibawah ini:

\section{a. Perkembangan Politik}

a) Periode Pertama (1972-1977)

Sebelum menjadi sebuah desa, wilayah Desa Laiba merupakan wilayah distrik La Kakoda. Kemudian setelah dimekarkan maka dipimpin oleh kepala desa. Perkembangan Desa Laiba dapat dilihat pada tabel berikut ini:

Tabel 6. Nama-Nama Kepala Kampung/Kepala Desa Laiba

\begin{tabular}{|l|l|l|l|}
\hline No. & Periode & Nama kepala desa & Keterangan \\
\hline 1 & Tidak diketahui & La Kakoda & Kino Laiba \\
\hline 2 & Tidak diketahui & La Ode Kambera & Kino Laiba \\
\hline 3 & Tidak diketahui & La Hubi & Kino Laiba \\
\hline 4 & Tidak diketahui & La Guari & Kino Laiba \\
\hline 5 & Tidak diketahui & La Ode Edje/aro jupanda & Kino Laiba \\
\hline 6 & Tidak diketahui & La Samuli & Kino Laiba \\
\hline 7 & Tidak diketahui & La Ode Asi/Aro Panata & Kino Laiba \\
\hline 8 & Tidak diketahui & La Kuje/Aro Laiba & Kino Laiba \\
\hline 9 & Tidak diketahui & La Ode Tuani/Aro Panganta & Kino Laiba \\
\hline 10 & $1972-1974$ & La Ode Muhammad & Kino Laiba \\
\hline 11 & $1974-1977$ & La Ode Jiino & Kino Laiba \\
\hline 12 & $1977-1983$ & La Ode Ntumade & Kepala Desa \\
\hline 13 & $1983-1989$ & La Dika & Kepala Desa \\
\hline 14 & $1989-1994$ & La Tia & Kepala Desa \\
\hline 15 & $1994-1999$ & D.rs Edi Ridwan & Kepala Desa \\
\hline 16 & $1999-2007$ & La Ode Ndomuka & Kepala Desa \\
\hline 17 & $2007-2014$ & Rahmat Sufa, S.Pd & Kepala Desa \\
\hline 18 & $2014-S e k a r a n g$ & La Jia & Kepala Desa \\
\hline
\end{tabular}

Sumber Data: Profil Desa Laiba Tahun 2017.

Dari tabel di atas dapat dijelaskan bahwa dalam pembangunan politik Desa Laiba diawali dengan banyaknya penduduk yang mendiami wilayah Desa Laiba dan pembentukan ini merupakan sebuah perintah dari wilayah setempat, dan merupakan kesepakatan pemerintah kabupaten pada waktu itu. Kemudian disusul dengan pemilihan dan penetapan kepala desa yang harus memimpin satu desa. Setelah adanya kepala desa maka mulailah pelaksanaan pemerintah yang mempunyai hak otonomi begitu seterusnya.

b) Periode Kedua (Akhir 1977-2007)

Pada periode ini terjadi perubahan besar karena pada masa ini dipimpin oleh kepala desa yang tegas dengan menerapkan aturan yang ketat bagi masyarakat dengan penjagaan desa yang ketat pula agar desanya aman. Awal periode ini dipimpin oleh Laode Ntumade dan terjadi perubahan pemerintahan dari Kino Laiba menjadi kepala desa dan La Ode Ntumade menjadi kepala desa pertama yang menjabat di desa ini.

c) Periode Ketiga (2007-sampai sekarang)

Periode ini dimulai pada tahun 2007 setelah pergantian kepala desa dari La Ode Ndomuka ke Rahmat Sufa, S.Pd. pada periode terjadi perubahan sangat pesat karena pada pemerintahan ini banyak pembangunan yang dilakukan. Seperti pembangunan Taman Kanak-Kanak, pembuatan lapangan sepak bola, pembuatan sumur gali. Selanjutnya pada masa pemerintahan La Jia, banyak melakukan perubahan seperti pembangunan kembali kantor balai desa, pembangunan mesjid, pembuatan jalan usaha tani, pembuatan drainase, dan lain sebagainya. Sejak pemerintahan La Jia Desa Laiba semakin berkembang. 
Pemerintah adalah organisasi yang memiliki kekuasaan untuk membuat dan menerapkan hukum serta undang-undang di wilayah tertentu. Pemerintah desa adalah penyelenggaraan urusan pemerintahan oleh pemerintah desa dan badan permusyawaratan desa dalam mengatur dan mengurus kepentingan masyarakat setempat berdasarkan asal-usul dan adat istiadat setempat yang diakui dan dihormati dalam sistem pemerintahan Negara Kesatuan Republik Indonesia.

\section{b. Perkembangan Pelayanan Umum}

Pemberian pelayanan yang baik kepada masyarakat diharapkan menjadi lebih respondesif terhadap kepentingan masyarakat itu sendiri. Perkembangan pelayanan umum mencakup pelayanan pemerintah terhadap masyarakat. Sebagaimana salah satu tugas kepala desa adalah membina ketentuan dan ketertiban hidup masyarakat desa. Perkembangan pelayanan umum Desa Laiba dapat dilihat dari tabel sebagai berikut:

Tabel 7. Pelayanan Umum Desa Laiba Tahun 2017

\begin{tabular}{|c|c|c|c|c|}
\hline \multirow[t]{2}{*}{ No. } & \multirow[t]{2}{*}{ Uraian } & \multicolumn{2}{|c|}{ Keberadaan } & Keterangan \\
\hline & & Ada & Tidak & \\
\hline 1. & Pelayanan kependudukan & Ada & & \\
\hline 2. & Pemakaman & Ada & & \\
\hline 3. & Perijinan & Ada & & \\
\hline 4. & Pasar tradisional & & Tidak & \\
\hline
\end{tabular}

Sumber Data: Profil Desa Laiba Tahun 2017.

Dari tabel di atas maka jelas bahwa pelayanan kependudukan dilaksanakan setiap hari jam kerja kadang kala ada penduduk yang datang pada sore hari, bahkan pada malam hari, hal ini bisa dimaklumi karena mayoritas penduduk adalah petani sehingga kesibukan bekerja seharian, disamping itu masyarakat awam tingkat pemahaman mengenai jam kerja masih kurang.

Berkaitan dengan efektivitas dan efesiensi pelayanan terhadap masyarakat di Desa Laiba dapat dilihat pada pelayanan yang diberikan oleh aparat pemerintah desa kepada masyarakat yang berkepentingan. Sehubungan dengan pelayanan ini ada beberapa indikator yang dijadikan sebagai ukuran untuk melihat efektivitasnya yaitu kesadara dan kebijaksanaan oleh kepala desa serta aparat pemerintah desa yang lain terhadap pelayanan masyarakat setempat. Pelayanan masyarakat sangat terkait dengan fungsi pemerintah desa dalam mengembangkan organisasi pemerintahanya baik itu terhadap kegiatan administrasi maupun dalam bidang pembangunan atau pelaksanaan pengawasan serta pembinaan terhadap masyarakat desa.

Desa Laiba belum terdapat pasar sehingga apabila masyarakat ingin menjual hasil pertanian maka mereka menjualnya di pasar desa tetangga yang jaraknya $7 \mathrm{~km}$ dari Desa Laiba. Sehubungan dengan itu UUD RI tentang Desa, telah disebutkan bahwa desa berkewajiban untuk memberikan dan meningkatkan pelayanan kepada masyarakat desa (Pasal 67, UU No. 6 Tahun 2014). Perizinan diantaranya izin keramaian dan izin tinggal. Izin keramaian diwajibkan bagi kegiatan yang bisa mendatangkan masa dalam jumlah banyak. Seperti hiburan rakyat dan orjen. Izin ini selain kepemerintah desa juga diteruskan ke kapolsek. Izin tinggal diberlakukan kepada warga asing yang bertamu dari 24 jam atau menginap terutama bukan keluarga dekat dengan warga setempat.

\section{c. Perkembangan Ekonomi}

Ekonomi pedesaan diperoleh berdasarkan hasil produksi dari daerah pedesaaan biasanya masih bersifat tradisional. Keuangan desa adalah semua hak dan kewajiban dalam rangka penyelenggaraan pemerintah desa yang dapat dinilai dengan uang termasuk didalamnya segala bentuk kekayaan yang berhubungan dengan hak dan kewajiban desa tersebut. Sebagaimana tertuang dalam Undang-Undang Nomor 6 tahun 2014 bahwa pendapatan desa bersumber dari; pendapatan asli desa terdiri atau hasil usaha, hasil aset, swadaya dan partisipasi, gotong royong dan lain-lain pendapatan asli desa; alokasi Anggaran Pendapatan dan Belanja Negara; bagi hasil pajak daerah dan netribusi daerah Kabupaten/Kota; alokasi dana desa yang merupakan bagian dari dana perimbangan yang terutama Kabupaten/Kota; bantuan keuangan dari Anggaran Pendapatan dan 
Belanja Daerah Provinsi dan Anggaran Pendapatan Belanja Daerah Kabupaten/Kota; hibah dan sumbangan yang tidak mengikat dari pihak ketiga; dan lain-lain pendapatan desa yang sah. Perkembangan ekonomi Desa Laiba dapat dilihat dalam dalam tabel di bawah ini:

Tabel 8. Kondisi Perkembangan Ekonomi Tahun 2017

\begin{tabular}{|c|c|c|c|c|c|}
\hline \multirow[t]{2}{*}{ No. } & \multirow{2}{*}{$\begin{array}{l}\text { Sumber } \\
\text { Penerimaan } \\
\text { Dana Desa }\end{array}$} & \multicolumn{4}{|c|}{ Tahun } \\
\hline & & $2014(\mathrm{Rp})$ & 2015 (Rp) & $2016(\mathrm{Rp})$ & 2017 (Rp) \\
\hline 1 & Pajak & 19.506 .172 & 19.506 .172 & 19.506 .172 & 19.506 .172 \\
\hline 2 & PNPM & 300.000 .000 & 300.000 .000 & - & - \\
\hline 3 & PPIP & 300.000 .000 & - & - & - \\
\hline 4 & $\mathrm{DD}$ & 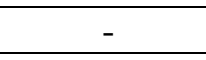 & 600.000 .000 & 600.000 .000 & 833.313000 \\
\hline
\end{tabular}

Sumber Data: Profil Desa Laiba Tahun 2017.

Dari tabel diatas dapat dijelaskan bahwa sumber penerimaan dana Desa Laiba tahun 2014-2017 berasal dari pajak, PNPM, DD, PPIP. Penerimaan pajak dari tahun 2014 s/d 2017 masih tetap sama, ini menunjukkan bahwa kesadaran masyarakat tentang pentingnya membayar pajak sudah meningkat sebagai salah satu sumber dana desa. Pada saat ini, hanya akan diuraikan tentang kondisi ekonomi masyarakat, mulai dari mata pencaharian, pendapatan, kekayaan, aset dan lain-lain. Pada aspek mata pencaharian, masyarakat Desa Laiba terdiri dari petani, PNS, peternak, pedagang, tukang kayu, pedagang, wirausaha dan lain-lain. Berdasarkan data desa tahun 2017 kelompok mata pencaharian terbanyak adalah petani dengan 710 . Namun seiring berjalannya waktu terkadang pekerjan masyarkat tidak menentu sehingga bisa mereka jalankan dua pekerjaan atau bahkan lebih. Dalam hal ini petani yang dimaksud bisa saja lain dari luar misalnya pedagang, tukang maupun yang lainnya. Sebagian besar masyarakat Desa Laiba menggantungkan hidupnya dibidang pertanian yang merupakan hasil budaya yang telah dilakukan dan dikembangkan secara turun temurun, apabila dilihat dari kondisi lingkungan alam dan penguasaan teknologi serta peralatan pertanian tersebut memang sangat cocok untuk dipilih sebagai salah satu alternatif pemenuhan kebutuhan hidup masyarakat.

Pada umumnya peran wanita dalam kegiatan pertanian cukup besar. Melibatkan wanita sebagai tenaga kerja utama dalam satu keluarga. Pembagian tugas antara pria dan wanita di kebun pada sistem usaha tani menurut pengalaman penulis, menunjukkan wanita berperan besar dalam tiga kegiatan pertanian, menanam, merawat tanaman, dan memanen. Sedangkan pria berperan besar dalam kegiatan pertanian yaitu membuka lahan, membuat pagar, dan mengelolah tanah kembali. Selain berperan dalam kegiatan pertanian, wanita juga berperan penting dalam pekerjaan rumah tangga, berjualan hasil kebun untuk menambah pendapatan keluarga serta mengelolah hasil kebun.

\section{d. Perkembangan Pendidikan}

Sejalan dengan perkembangan ekonomi masyarakat Desa Laiba yang semakin meningkat, maka kepentingan-kepentingan keluarga mulai dapat terpenuhi dengan baik, bahkan anak-anak mereka sudah dapat meningkatkan pendidikan dengan baik dan sempurnah, mulai dari pendidikan $\mathrm{SD}$, sampai pada tingkat pendidikan tinggi terutama dilingkungan universitas. Perkembangan pendidikan di Desa Laiba pada khususnya Kecamatan Parigi pada umumnya mengalami perkembangan pendidikan yang sudah dapat dikatakan sudah lebih baik. Terbukti dengan adanya beberapa sarana pendidikan yang terdapat di Desa Laiba antara lain, TK, dan 2 SD. Dengan adanya sarana pendidikan tersebut maka jumlah anak sekolah tiap tahunnya terus bertambah.

Berdasrkan kenyataan yang ada berarti kesadaran masyarakat terkait hal pentingnya suatu pendidikan semakin meningkat. Sehubungan dengan hal ini berarti kesadaran pihak orang tua untuk menyekolahkan anak-anaknya keberbagai jenjang sudah cukup baik, ditambah dengan berbagai kemudahan serta kebijaksanaan pemerintah menyangkut masalah pendidikan bagi masyarakat dibuktikan dengan adanya sarana dan prasarana yang berupa penambahan tenaga kerja serta perlengkapan lainnya. Adanya kesadaran masyarakat yang demikian itu, dapat dilihat dari sikap dan pola pikir serta wawasan mereka terhadap masalah pendidikan. Masalah pendidikan tidak dapat dilepas pisahkan dari kehidupan seseorang, dan pendidikan mempunyai hubungan serta 
langsung dengan kehidupan manusia. Krena dengan pendidikan manusia bisa memperoleh suatu penghidupan yang layak dalam memenuhi kebutuhannya. Pendidikan juga dapat berdasrkan kehidupan bangsa (wawancara La Jia, 09 Oktober 2018). Jika kita mencermati hal diatas, bahwa mereka tidak menginginkan pada suatu kelak nanti anak-anak mereka harus hidup seperti yang mereka alami, dimana mereka pada umumnya hanya memperoleh pendidikan sampai pada tingkat Sekolah Dasar. Sehingga sulit bagi mereka untuk memperoleh pekerjaan yang layak bagi kehidupannya diera perkembangan dan persaingan IPTEK sekarang ini.

\section{e. Perkembangan Sarana dan Prasarana}

Sarana adalah segala sesuatu yang dipakai sebagai alat untuk mencapai makna dan tujuan. Sedangkan prasarana adaah segala sesuatu yang merpakan penunjang utama terselenggaranya suatu proses. Jika dilihat dari perkembangan sarana dan prasarana Desa Laiba semakin berkembang. Saran yang ada di Desa Laiba seperti pendidikan sudah lebih baik ini terbukti bahwa di Desa laiba dua buah memiliki sekolah dasar dan satu taman kanak-kanak. Untuk menunjang taraf hidup masyarakat Desa Laiba, pemerintah menyadari harus membangun sejumlah infrastruktur seperti jalan desa yang menghubungkan akses jalan kabupaten. Hal ini memudahkan arus transportasi, sehingga memudahkan masyarakat setempat dalam memasarkan hasil produksi pertaniannya yang menjadi andalan dalam memenuhi kebutuhan sehari-hari.

Sehubungan dengan bidang pelayanan masyarakat, dalam hal ini infrastruktur pemerintah sudah cukup bagus. Pemerintah juga membangun sarana pemerintahan sebagai pusat pelayanan, baik dibidang pengurusan administrasi kependudukan, maupun sosialisasi penyuluhan pertanian. Hal ini akan lebih mempermudah mengadukasi masyarakat dalam hal kegiatan pertanian ditambah juga adanya bantuan seperti bibit pertanian, pupuk, strom babi, dan alat-alat untuk mengolah lahan pertanian. Ini sangat membantu masyarakat setempat untuk lebih meningkatkan hasil produksi pertanianaya. Hingga saat ini sejumlah program pemerintah seperti Program Nasional Pemberdayaan Masyarakat (PNPM) terealisasi dengan baik sesuai dengan sarananya seperti pembuatan jalan tani, pengersan lorong, pembuatan sumur Gali dan pembuatan WC. Dengan adanya jalan tani maka akses menuju kebun mereka tidak lagi memakan waktu yang lama, seperti sebelumnya hanya bisa dilalui dengan berjalan kaki. Setelah adanya usaha jalan tani sudah bisa dilalui dengan menggunakan roda empat (mobil) dan roda dua (sepeda dan motor).

Selain itu pemerintah membangun fasilitas kesehatan berupa puskesmas dan posyandu untuk memudahkan pelayanan kesehatan masyarakat. Sehingga soal pengobatan dasar masyarakat tidak lagi harus menuju kekota yang aksesnya cukup jauh dari Desa Laiba. Melalui adanya puskesmas dan posyandu membuat masyarakat tidak lagi menggantungkan diri kepada dukun setempat uang selama ini dipercaya. mengenai sarana prasarana dapat dilihat melalui tabel berikut:

Tabel 9. Sarana Dan Parasarana Desa Laiba Tahun 2017

\begin{tabular}{|l|l|l|l|}
\hline No. & $\begin{array}{l}\text { Tah } \\
\text { un }\end{array}$ & Kegiatan pembangunan & Keterangan \\
\hline 1. & 1979 & Pembangunan Kantor Desa & Swadaya \\
\hline 2. & 1983 & Pembangunan Balai Pertemuan Desa & DPD/K \& Swadaya \\
\hline 3 & 1984 & Pembangunan Mesjid Al-Kautsar & Swadaya \\
\hline 4. & 1985 & Pembangunan Gedung Sanggar PKK & DPD/K \& Swadaya \\
\hline 5. & 1999 & Pembangunan Jalan Usaha Tani Dusun I & PKK \\
\hline 6. & 2002 & Pembangunan Perkersan Jalan Dusun II & PKK \\
\hline 7. & 2005 & Pembangunan Jalan Laiba-Latampu & PPIP \\
\hline 8. & 2008 & Pembuatan Lapangan Sepak Bola & APBD I \\
\hline 9. & 2009 & Pembangunan Sumur Gali & PNPM \\
\hline 10 & 2010 & Pembangunan Gedung Tk & PNPM \\
\hline 11. & 2014 & Pembangunan Jalan Usaha Tani & PNPM \\
\hline 12. & 2015 & Pembangunan Jalan Lingkungan, Pembangunan Mesjid & PNPM \\
\hline 13. & 2016 & Pembangunan Jalan Usaha Tani (3 Km) & Dana Desa \\
\hline
\end{tabular}


E-ISSN: 2502-6674

P-ISSN: 2502-6666

http://ojs.uho.ac.id/index.php/p_sejarah_uho

\begin{tabular}{|l|l|l|l|}
\hline 14. & 2017 & Pembangunan Balai Gedung Serba Guna & Dana Desa \\
\hline 15. & 2017 & Drainase & Dana Desa \\
\hline 16 & 2017 & Pembangunan jalan menuju goa lamburaea $(7 \mathrm{~km})$ & Dana desa \\
\hline 17 & 2017 & Perkerasan jalan menuju permandian kaoeoe $(2 \mathrm{~km})$ & Dana desa \\
\hline 18 & 2017 & Pengadaan pupuk 20 karung & Dana desa \\
\hline 19 & 2017 & Pengadaan bibit jagung harum manis & Dana desa \\
\hline
\end{tabular}

Sumber Data: Profil Desa Laiba Tahun 2017.

Dari tabel diatas dapat dijelaskan bahwa pembangunan Desa Laiba mulai mengadakan pembangunan pada masa pemerintahan La Ode Ntumade 1979-1983 yang berupa kantor desa, pembanguan balai pertemuan. Kemudian pembangun pada tahun 1984-1989 pada masa pemerintahan La Dika terlihat dua aspek pembanguan yakni pembangunan mesjid al-kautsar dan pembangunan gedung sanggar PKK. Selanjutnya pada masa pemerintahan La Tia pada tahun 19891994 pembanguanan yang dilakukan yakni pembangunan jalan usaha tani dusun I. Kemudian pada tahun 1999-2007 semasa pemerintahan La Ode Ndomuka pembanguanan yang dilakukannya adalah pembanguanan perkerasan jalanan dusun II dan pembangunan jalan Laiba-Latampu. Pada masa pemerintahan Rahmat Sufa pada tahun 2007-2014 pembangunan yang dilakukannya adalah pembuatan lapangan sepak bola, pembangunan sumur gali, dan pembangunan sumur gali. Selanjutnya pada masa pemerintahan La Jia sampai sekarang pembangunan yang dilakukannya adalah pembanguan kembali kantor desa, balai pertemuan, perkerasan jalan Laiba-Labulu, pembangunan mesjid.

Sejak pemerintahan La Ode Ntumade tahun 1979-1983 Kantor Desa Laiba telah dibangun dan selanjutnya pada pemerintahan Rahmat Sufa di kantor balai desa lama telah di renovasi. Kemudian pemerintahan selanjutnay yang dipimpin oleh La Jia, pada tahun 2014-sekarang ia membangu sebuah kantor balai desa yang baru. Ini menunjukkan bahwa dari segi sarana dan prasarana di Desa Laiba semakin berkembang. Selain itu juga La Jia telah banyak melakukan pembangunan dari berbagai sektor seperti pembangunan mesjid, pembangunan jalan, pengadaan pupuk, pengadaan bibit jagung dan lain sebagainya.

Alasan utama La Jia membangun mesjid bahwa ia berpikir semua penduduk desa Laiba adalah mayoritas muslim dan untuk meningkatkan keimanan masyarakatnya. Berdasrkan hasil wawancara dari beberapa orang informan dan setelah melihat kondisi sekita Desa Laiba maka penulis menyimpulkan bahwa perkembangan Desa Laiba yang cukup signifikan, ditambah dengan faktor penduduk, sumber daya manusia dan sumber daya alam serta luas wilayah sudah memenuhi syarat dan ketentuan. Berdasarkan penjelasan diatas terbukti bahwa adanya perkembangan dari berbagai aspek kehidupan masyarakat.

\section{PENUTUP}

Berdasarkan hasil penelitian yang telah dipaparkan penulis pada bab sebelumnya, maka dapat di simpulkan bahwa: Latar belakang terbentuknya Desa Laiba Kecamatan Parigi Kabupten Muna adalah: Desa Laiba bukanlah desa yang baru di bentuk, desa ini terbentuk sejak tahun 1978. Terbentuknya desa ini tidak terlepas dari peran para pemimpin dan tokoh adat sebagai motivator dan dinamisator. Selain itu juga terbentuknya Desa Laiba karena faktor geografis dan faktor demografi. Nama desa Laiba diambil dari salah satu orang nama penduduk Desa Laiba yang pertama kali ditemui oleh La Kakoda yaitu"La Iba"

Perkembangan Desa Laiba Kecamatan Parigi Kabupaten Muna Tahun 1978-2017 jika dilihat secara umum dapat disimpulkan bahwa perkembangan politik yang ada di Desa Laiba sudah cukup baik meskipun pada tahun 2014 kondisi politiknya gaduh akan tetapi setelah berjalannya waktu keadaan itu sudah kembali stabil. Kemudian dari segi ekonomi menunjukkan sudah lebih baik dan maju menuju arah yang semakin sejahtera dengan memanfaatkan potensipotensi sumber daya alam yang ada di Desa tersebut. Selanjutnya karena kondisi ekonomi sudah cukup baik maka keadaan pendidikanpun ikut membaik, sarana dan prasaranapun yang ada di desa 
E-ISSN: 2502-6674

P-ISSN: 2502-6666

http://ojs.uho.ac.id/index.php/p_sejarah_uho

ini semakin memadai. Sedangkan keadaan sosial budaya Desa Laiba menunjukkan keadaan yang lebih baik.

\section{DAFTAR PUSTAKA}

Arifin. 1987. Gagasan Pembaharuan Muhammadiyah Dalam Pendidikan. Jakarta: Dunia Pusat Jaya

Busroh, Abu Daud. 1990. Ilmu Negara. Jakarta: Bumi Aksara

Davis, Gordon B. 2000. Kerangka Dasar Sistem Informasi Manajemen. Jakarta: Pustaka Binatama Pressindo

Gie, The Liang. 1997. Pertumbuhan Pemerintah Daerah di Negara Republik Indonesia. Yogyakarta : Liberty.

Sabarno, Hari. 2007. Memandu Otonomi Daerah Menjaga Kesatuan Bangsa. Jakarta: Sinar Grafika.

Kuntowijoyo. 1995. Pengantar Ilmu Sejarah. Yogyakarta. Tiara Wicana.

Peribadi. 2017. Sosiologi Perdesaan. Yogyakarta: Deepublish.

Hugiono dan P. K Poerwantana. 1984. Pengantar ilmu Sejarah. Jakarta: Balai Pustaka

Nur, Rifai. 2014. Dari Daerah untuk Indonesia. Kendari: Press Kendari.

Ruslan. 1999. "Terbentuknya Desa Teppoe Kecamatan Poleang Timur. Kabupaten Buton.(Suatu Tinjauan Sejarah Tentag Komunitas Sku Bugis)". Skripsi. Kendari. FKIP: Unhalu.

Sitti Rahmatun. 2014. "Sejarah Desa Raimuna Kecamatan Maligano Kabupaten Muna Tahun 1997-2014". Skripsi: FKIP Unhalu.

Soekanto, Soerjono. 2015. Sosiologi Suatu Pengantar: Jakarta. Raja Grafindo

Surbakti, Ramlan. 1992. Memahami Ilmu Politik. Jakarta: Gramedia Widiasarana Indonesia.

S, Pamudji. 1985. Analisa Administarsi: Analisa Sistem-Sistem Bagi Administrasi Yang Efektif: Bina Aksara.

Suelem, I Made. 1998. "Terbentuknya Desa Jati Bali di Kecamatan Ranomeeto Kabupaten Kendari”. Skripsi. Kendari: FKIP Unhalu.

Ratnawati, Tri. 2015. Pemekaran Wilayah dan Alternatif Pemecahan Wilayah: Refisi Mendasar Terhadap PP 129 Tahun 2000. Jakarta: Yayasan Harkat Bangsa.

Widjaja, HAW. 2002. Otonomi Darah dan Daerah Otonom. Jakarta: Raja Grafindo Persada. 